\title{
F1-hybridimenetelmän kehittäminen kevätrypsille
}

Tarja Niemelä, Mervi Seppänen ja Unto Tulisalo

Helsingin yliopisto, Soveltavan biologian laitos, PL 27, 00014 Helsingin yliopisto, etunimi.sukunimi@helsinki.fi

\section{Tiivistelmä}

Kevätrypsin satotason nostaminen on yksi öljykasvien viljelyn keskeisimmistä tavoitteista. Hybridirypsit mahdollistaisivat satotason nostamisen vähintään 10 - $20 \%$ :lla sekä lisäisivät elinvoimaisuutta ja satovarmuutta vaihtelevissa kasvuoloissa. Tässä hankkeessa tavoitteena oli siirtää Kosena-nimellä kulkeva hybridimenetelmä kevätrapsilta kevätrypsiin ja testata menetelmän toimivuus rypsillä. Lisäksi tutkittiin Kosena-menetelmän yhteensopivuus hyvin homologisen, Ogura-menetelmän, kanssa.

Hybridisiemen perustuu siementuotantomenetelmään, jossa valitut vanhempaislinjat saadaan risteytettyä keskenään. Yksi käyttökelpoisimmasta menetelmistä on sytoplasmaattisen koirassteriliteetin hyödyntäminen (CMS, sytoplasmic male sterility). Menetelmä perustuu solulimassa sijaitseviin perintötekijöihin, joiden vaikutuksesta heteet eivät muodosta siitepölyä. Tämä linja on äitilinja. Isälinja sen sijaan tuottaa siitepölyä ja toimii äitilinjan pölyttäjänä. Lisäksi isälinjan perintötekijät sisältävät ns. palauttajageenin (Rf, restor fertility), joka palauttaa normaalin siitepölymuodostuksen viljeltävään hybridiin.

Tässä hankkeessa käytettiin japanilaisten tutkijoiden retikalta löytämää ja kevätrapsiin siirtämää Kosena-sytoplasmaa ja -palauttajageeniä. Tähän mennessä rypsin hybridilajikkeiden jalostus on pysähtynyt sopivan palauttajageenin puuttumiseen. Kosena-menetelmän geenit siirrettiin rapsilta rypsille perinteisellä takaisinristeytyksellä. Takaisinristeytyssukupolvien välissä sekä CMS- että Rf-tekijöiden siirtyminen varmennettiin PCR (poly chain reaction) -tekniikalla.

Tutkimuksen tulokset vahvistivat Kosena- ja Ogura-menetelmien yhteensopivuuden. Kosenamenetelmän isälinja palautti siitepölytuotannon myös Ogura-sytoplasmalla, joten menetelmät ovat niin lähellä toisiaan, että niitä voidaan käyttää yhdessä. Tekemiemme vertailujen mukaan Ogura-sytoplasma toimii rypsillä paremmin kuin Kosena-sytoplasma.

Siitepölymuodostuksen palauttava Rf-tekijä onnistuttiin siirtämään kevätrapsilta kevätrypsille tavanomaisella takaisinristeytyksellä. Kasvit olivat kuuden takaisinristeytyssukupolven jälkeen tyypiltään jo selvästi rypsimäisiä. Jälkeläistö oli tässä vaiheessa vielä heterotsygootti, mutta fertiilit kasvit omasivat hyvin kehittyneet heteet, jotka muodostivat runsaasti siitepölyä. Tekijän yhtenäistäminen ja saaminen homotsygoottiin muotoon toteutettiin itsesiitoksella. Menetelmä vaatii vielä lisäselvitystä sekä geenin pysyvyyden, että siementuotantomenetelmän toimivuuden suhteen.

Asiasanat: Kevätrypsi, hybridimenetelmä, Kosena, Ogura 


\section{Johdanto}

Kevätrypsin alhaiseen satotasoon on toivottu parannusta jo useiden vuosien ajan. Tietopalvelukeskuksen (TIKE) keräämien tietojen mukaan kevätrypsin keskisadot ovat pudonneet 1990-luvun alun noin 1700 $\mathrm{kg} / \mathrm{ha}$ 2000-luvun noin $1300 \mathrm{~kg} / \mathrm{ha}$. Yksi keino nostaa kevätrypsin satotasoa on hybridilajikkeiden tuominen viljelyyn. Hybridirypsien viljely mahdollistaisi satotason nostamisen vähintään $10-20 \%$ :lla (Schuler et al. 1992, Falk et al. 1994, Falk et al. 1998) ja lisäisi samalla lajikkeiden elinvoimaisuutta ja viljelyvarmuutta vaihtelevissa kasvuoloissa.

Hybridilajikkeiden tuominen viljelyyn hyödyntää heteroosi-ilmiötä ja sen satoa nostavaa vaikutusta. Sen käyttö edellyttää siementuotantomenetelmää, jolla vanhempaislinjat voidaan risteyttää keskenään. Yksi käyttökelpoisimmasta menetelmistä on sytoplasmaattisen koirassteriliteetin hyödyntäminen (CMS, sytoplasmic male sterility). Menetelmä perustuu solulimassa sijaitseviin perintötekijöihin, joiden vaikutuksesta heteet eivät muodosta siitepölyä. Tämä linja on äitilinja. Isälinja sen sijaan tuottaa siitepölyä ja toimii äitilinjan pölyttäjänä. Lisäksi isälinjan perintötekijät sisältävät ns. palauttajageenin (Rf, restor fertility), joka palauttaa normaalin siitepölymuodostuksen viljeltävään hybridiin.

Rapsihybrideillä on kaupallisessa lajiketuotannossa käytössä Ogura-nimellä kulkeva cms-Rf - menetelmä. Steriiliyden aiheuttava ja siitepölytuotannon takaisin palauttava geeni on molemmat löydetty retikalta ja menetelmä on saanut nimen löytäjänsä mukaan (Fu ja Yang 1998). Tähän mennessä rypsin hybridilajikkeiden jalostus on pysähtynyt sopivan palauttajageenin puuttumiseen. Ogura-sytoplasma saa aikaan pysyvän steriliteetin myös rypsillä, mutta palauttajageeni sijaitsee rapsilla kaalin genomissa, eikä sitä ole onnistuttu siirtämään rypsille perinteisellä takaisinristeytysmenetelmällä.

Japanilaiset tutkijat löysivät retikalta toisen, hyvin lähellä Ogura-menetelmää, olevan cms-Rf- menetelmän (Sakai et al. 1996, Iwabuchi et al. 1999, Koizuka et al. 2000). Menetelmä sai nimekseen Kosena, retikan lajikkeen mukaan. Tutkijoiden mukaan Kosena-hybridimenetelmä saattaisi toimia myös rypsillä, minkä vuoksi menetelmää lähdettiin testaamaan. Tutkimuksen tavoitteena oli siirtää Kosena-menetelmä kevätrapsilta kevätrypsiin ja testata menetelmän toimivuus rypsillä. Lisäksi tutkittiin Kosena-menetelmän yhteensopivuus Ogura-menetelmän kanssa.

\section{Aineisto ja menetelmät}

Tutkimus suoritettiin Helsingin yliopiston Soveltavan biologian laitoksella vuosina 2002 - 2005. Tutkimus oli jatkoa Mildolassa jo 80-luvun lopulla aloitetulle kevätrypsin hybridijalostusohjelmalle, jonka puitteissa oli tuotettu vanhempaislinja-aineisto ja testattu niiden heteroosiominaisuuksia lajikekokeilla. Rypsilinjoista valittiin tutkimukseen kolme sadontuotoltaan ja viljelyominaisuuksiltaan parasta linjaa. Hybridijalostusohjelman aikana valittuihin kevätrypsilinjoihin oli jo siirretty INRA'n Ogura-sytoplasma. Kosenamenetelmän siirtämiseksi rypsilinjoihin tarvittavat Kosena-sytoplasma ja -palauttajageeni saatiin Japanilaiselta Plantech'ltä. Lisäksi tutkimuksessa oli Mildolan rapsin hybridiohjelmasta kaksi äitilinjaa Ogurasytoplasmalla.

Ogura- ja Kosena-menetelmien yhteensopivuutta testattiin kevätrapsilla kasvihuonekokein. Kokeessa risteytettiin Kosena-isälinjalla sekä Ogura (2 kpl)- että Kosena-äitilinjoja (1 kpl). F1-sukupolven hybrideistä havainnoitiin siitepölyn muodostuminen ja siitepölyn toimivuus.

Kosena-menetelmän siirtäminen kevätrapsilta rypsiin toteutettiin tavanomaisella takaisinristeytyksellä. Takaisinristeytyssukupolvia tehtiin kuusi, mikä on yleisesti riittävä. Tällöin 99,6 \% perintöaineksesta on jo rypsin puolelta. Takaisinristeytyssukupolvien välissä jatkoon valituista yksilöistä testattiin PCR (poly chain reaction) - menetelmällä cms- ja Rf-geenien mukanaolo.

\section{Tulokset ja tulosten tarkastelu}

\section{Ogura-ja Kosena-menetelmien yhteensopivuus}

Ogura- ja Kosena-menetelmä ovat erittäin lähellä toisiaan geenien rakenteen ja toimintamekanismin osalta. Kosenan Rf-geenin on raportoitu palauttavan siitepölytuotannon myös Ogura-sytoplasmalla. Kasvihuone- 
kokeissa Kosena-isälinjalla pölytettiin sekä Ogura- että Kosena-äitilinjoja. F1-hybridit olivat kaikissa tapauksissa täysin fertiileitä (Taulukko 1.). Silmämääräisten havaintojen perusteella heteet olivat normaalin kokoiset ja muodostivat runsaasti siitepölyä. Siitepölyn elävyys testattiin pussittamalla jokainen F1hybridi ja katsomalla, jos kasvi pystyy pölyttämään itse itsensä ja muodostamaan lituja ja siemeniä. Kaikissa tapauksissa siitepöly oli toimivaa ja kasvit muodostivat lituja ja siemeniä normaalisti (Talukko 2.).

Taulukko 1.Fertiliteetin palautuminen F1-kasveissa

\begin{tabular}{l|ccc}
\hline Risteytys & Kasvien lkm & Fertiilit & Steriilit \\
\hline Rapsi (kos cms) x Rapsi (kos Rf) 1. & 8 & 8 & 0 \\
Rapsi (kos cms) x Rapsi (kos Rf) 2. & 8 & 8 & 0 \\
& & & \\
Rapsi (ogu cms) 1. x Rapsi (kos Rf) 1. & 8 & 8 & 0 \\
Rapsi (ogu cms) 1. x Rapsi (kos Rf) 2. & 8 & & 0 \\
& & 8 & 0 \\
Rapsi (ogu cms) 2. x Rapsi (kos Rf) 1. & 8 & 8 & 0 \\
Rapsi (ogu cms) 2. x Rapsi (kos Rf) 2. & 8 & \\
\hline
\end{tabular}

Taulukko 2. Litujen ja siementen muodostuminen F1-kasveissa

\begin{tabular}{|c|c|c|c|c|}
\hline Risteytys & $\begin{array}{l}\text { Sivuv. lkm } \\
\text { Ka } \pm(s d)\end{array}$ & $\begin{array}{l}\text { Lidut/pv } \\
\text { Ka } \pm(s d)\end{array}$ & $\begin{array}{l}\text { Lidut/sv } \\
K a \pm(s d)\end{array}$ & $\begin{array}{l}\text { Siemeniä/litu } \\
\operatorname{Ka} \pm(s d)\end{array}$ \\
\hline Rapsi (kos cms) x Rapsi (1 & $3,4 \pm(0,5)$ & $36,4 \pm(4,0)$ & $46,8 \pm(10,1)$ & $23,3 \pm(6,6)$ \\
\hline Rapsi (kos cms) x Rapsi (kos Rf) 2 . & $2,7 \pm(0,5)$ & $34,4 \pm(4,1)$ & $32,1 \pm(12,4)$ & $16,3 \pm(7,1)$ \\
\hline Rapsi (ogu cms) 1. x Rapsi (kos Rf) 1. & $3,4 \pm(0,7)$ & $36,9 \pm(8,6)$ & $26,0 \pm(5,6)$ & $18,2 \pm(9,5)$ \\
\hline Rapsi (ogu cms) 1. x Rapsi (kos Rf) 2. & $4,3 \pm(0,9)$ & $25,1 \pm(9,6)$ & $33,8 \pm(12,6)$ & $20,2 \pm(6,9)$ \\
\hline Rapsi (ogu cms) 2. x Rapsi (kos Rf) 1. & $4,0 \pm(0,0)$ & $33,9 \pm(4,9)$ & $59,6 \pm(11,2)$ & $11,1 \pm(8,3)$ \\
\hline Rapsi (ogu cms) 2. x Rapsi (kos Rf) 2. & $2,8 \pm(0,7)$ & $34,5 \pm(5,1)$ & $35,0 \pm(10,7)$ & $19,7 \pm(8,0)$ \\
\hline
\end{tabular}

Sivuversojen (sv) ja litujen lukumäärät on laskettu kahdeksan kasvin keskiarvona ja siementen lukumäärä pääverson (pv) viiden alimman lidun keskiarvona.

\section{Kosena-sytoplasman sïrto rapsilta rypsiin}

Kosena-sytoplasma siirrettiin kevätrapsilta rypsiin tavanomaisella takaisinristeytyksellä. Ensimmäisten takaisinristeytyssukupolvien aikana kasvit kärsivät lajien (rapsi x rypsi) välisestä risteytyksestä, mikä näkyi kasvuhäiriöinä ja huonona pölyttymisenä. Kasvuhäiriöt ilmenivät mm. jurovana tai pensastavana kasvutapana, kloroosina lehdissä ja kukkien epämuodostumina. Takaisinristeytyssukupolvesta toiseen siirryttäessä risteytykset tehtiin valittuihin kasveihin. Valintaperusteena oli mahdollisimman rypsimäinen ja täysin steriili yksilö, jolla oli selkeästi vajaasti kehittyneet ja täysin kaljut heteet. Valintaprosessi näkyy steriliteetin suurina muutoksina eri sukupolvissa (Taulukko 3.). Valinnasta huolimatta, linjoissa 4016 ja 4021, steriliteetti näytti purkautuvan selvimmin eli osittain siitepölyä muodostavia ja jopa täysin fertiilejä kasveja muodostui jälkeläistössä. Viidennessä takaisinristeytyssukupolvessa 4016-linjan steriliteetti oli vain $25 \%$ ja 4021-linjan $47 \%$. Linjassa 4003 steriliteetti säilyi parhaiten (98 \%), mutta kas vit kärsivät huomattavasti mm. nuppujen kuivumisesta ja aukeamattomuudesta. Tällaiset kasvuongelmat kukkien nupuissa merkitsisivät käytännön siemenlisäyksessä huomattavaa siemensadon alenemista. Tutkimuksen perusteella Kosena-sytoplasmaa ei voi suositella rypsin hybridisiementuotantoon. Ogura-sytoplasma saa rypsillä yleisesti aikaan pysyvän steriliteetin, ja koska Kosena-isälinja näyttää palauttavan siitepölytuotannon 
myös Ogura-äitilinjoissa, kannattaa rypsillä tässä tapauksessa valita Ogura-sytoplasma hybridisiementuotantoon.

Taulukko 3. Kosena cms: Steriliteetti eri takaisinristeytyssukupolvissa

\begin{tabular}{|c|c|c|c|c|}
\hline Linja & $\begin{array}{l}\text { Risteytys- } \\
\text { sukupolvi }\end{array}$ & Steriilit (\%) & $\begin{array}{c}\text { Osittain } \\
\text { steriilit (\%) }\end{array}$ & Fertiilit (\%) \\
\hline \multirow[t]{6}{*}{4003} & $B C 1 F 1$ & 97 & 1.5 & 1.5 \\
\hline & $B C 2 F 1$ & 39 & 45 & 16 \\
\hline & $B C 3 F 1$ & 100 & & \\
\hline & $B C 4 F 1$ & 97 & 3 & \\
\hline & $B C 5 F 1$ & 97 & 3 & \\
\hline & $B C 6 F 1$ & 98 & 1 & 1 \\
\hline \multirow[t]{5}{*}{4016} & $B C 1 F 1$ & 100 & & \\
\hline & $B C 2 F 1$ & 97 & 3 & \\
\hline & $B C 3 F 1$ & 91 & 9 & \\
\hline & $B C 4 F 1$ & 97 & 3 & \\
\hline & $B C 5 F 1$ & 25 & 69 & 6 \\
\hline \multirow[t]{5}{*}{4021} & $B C 1 F 1$ & 100 & & \\
\hline & $B C 2 F 1$ & 81 & 18 & 1 \\
\hline & $B C 3 F 1$ & 60 & 31 & 9 \\
\hline & $B C 4 F 1$ & 100 & & \\
\hline & $B C 5 F 1$ & 47 & 42 & 11 \\
\hline
\end{tabular}

Kustakin linjasta on havainnoitu 30-60 kasvia/sukupolvi.

\section{Kosenan Rf-geenin siirto rapsilta rypsiin}

Kosenan Rf-geenin siirto kevätrapsilta rypsiin toteutettiin samoin tavanomaisella takaisinristeytyksellä. Ensimmäisten sukupolvien aikana ilmenneet kasvuhäiriöt olivat samantyyppisiä kuin sytoplasman kohdalla. Kolmannen takaisinristeytyksen jälkeen kasvit olivat ulkoisilta ominaisuuksiltaan jo hyvin rypsimäisiä, eikä kasvuhäiriöitä enää esiintynyt merkittävästi. Takaisinristeytykset rypsiin aloitettiin Ogura-äitilinjoihin, koska tällöin Rf-geenin mukana oloa voi seurata silmävaraisin havainnoin. Samalla saatiin myös tieto siitä, että Kosenan Rf-geeni palauttaa siitepölytuotannon rypsin Ogura-äitilinjoissa. Rf-geenin mukana olo varmistettiin myös PCR-testillä.

Kosenan Rf-geeni toimii rapsilla kuten yksi dominoiva geeni. Tällöin jokaisen takaisinristeytyssukupolven jälkeläistön tulisi jakautua suhteessa 1:1 fertiileihin ja steriileihin. Fertiilien keskimääräinen osuus oli kuitenkin vain noin $30 \%$ (Taulukko 4.). Japanilaisten tutkijoiden antaman tiedon mukaan Rfgeeni on heterotsygootissa muodossa epästabiilimpi, mikä selittäisi kyseisen ilmiön myös rypsillä. Rfgeeni yhtenäistettiin homotsygoottiin muotoon itsesiitoksella. Kyseiset kolme rypsin Kosena-isälinjaa tullaan tutkimaan jatkossa geenin pysyvyyden ja siementuotantomenetelmän toimivuuden suhteen tarkem$\min$. 
Taulukko 4. Kosena Rf: Fertiilien osuus prosentteina eri takaisinristeytyssukupolvissa

\begin{tabular}{l|ccccc}
\hline Linja & BC2F1 & BC3F1 & BC4F1 & BC5F1 & BC6F1 \\
\hline 4003 & 34 & 28 & 22 & 38 & 31 \\
4016 & 25 & 22 & 28 & 31 & 41 \\
4021 & 38 & 35 & 47 & 41 & 32 \\
\hline Yhteens $\ddot{a}$ & $\mathbf{3 5}$ & $\mathbf{2 9}$ & $\mathbf{3 2}$ & $\mathbf{3 6}$ & $\mathbf{3 5}$ \\
\hline
\end{tabular}

Kussakin sukupolvessa on havainnoitu noin 30 kasvia/linja, paitsi BC6-sukupolvessa 150 kasvia/linja.

\begin{abstract}
Johtopäätökset
Rypsin mahdollinen hybridimenetelmä näyttäisi tämän tutkimukseen mukaan koostuvan Ogura- ja Kosena-menetelmien yhdistelmästä. Kosena-sytoplasma, joka saa aikaan rapsilla pysyvän steriliteetin, osoittautui rypsillä toimimattomaksi. Steriliteetti ei vakiintunut takaisinristeytysten jatkuessa, vaikka sukupolvien välissä käytettiin valintaa. Parhaiten steriliteetin säilyttäneessä linjassa esiintyi lisäksi kukinnassa kasvuhäiriöitä, jotka vaikuttaisivat käytännön siemenlisäyksessä satoa alentavasti. Kosenan isälinja palautti kuitenkin siitepölymuodostuksen F1-hybridiin sekä Ogura- että Kosena-sytoplasmalla. Tämä mahdollistaa hybridimenetelmän käytön rypsillä, sillä Ogura-sytoplasma, joka saa rypsillä aikaan pysyvän steriliteetin, olisi palautettavissa Kosenan isälinjalla. Kosenan palauttaja-geenin takaisinristeytyksessä rypsiin havaittiin geenin osittainen pysymättömyys heterotsygootissa muodossa. Kyseinen ilmiö on havaittu myös rapsilla. Geeni yhtenäistettiin rypsillä homotsygoottiin muotoon ja rypsin ensimmäisistä Kosena-isälinjoista tullaan jatkossa tutkimaan geenin pysyvyys ja siementuotantomenetelmän toimivuus tarkemmin.
\end{abstract}

\title{
Kirjallisuus
}

Falk, K. C., Rakow, G., Downey, R. K. and Spurr, D. T. 1994. Performance of inter-cultivar summer turnip rape hybrids in Saskatchewan. Can. J. Plant Sci. 74: $441-445$.

Falk, K. C., Rakow, G. F. W. and Downey, R. K. 1998. The utilization of heterosis for seed yield in hybrid and synthetic cultivars of summer turnip rape. Can. J. Plant Sci. 78: $383-387$.

Fu, T.D. and Yang, G.S. 1998. Rapeseed and Mustard. In: Banga, S.S. and Banga, S.K. (eds). Hybrid cultivar development. Springer-Verlag and Narosa Publishing House, pp. 402 - 431.

Iwabuchi, M., Koizuka, N., Fujimoto, H., Sakai, T. and Imamura, J. 1999. Identification and expression of Kosena radish (Raphanus sativus cv. Kosena) homologue of the ogura radish CMS-associated gene, orf138. Plant Mol. Biol. 39, 183 - 188.

Koizuka, N., Imai, R., Iwabuchi, M., Sakai, T. and Imamura, J. 2000. Genetic analysis of fertility restoration and accumulation of ORF125 mitochondrial protein in the kosena radish (Raphanus sativus cv. Kosena) and Brassica napus restorer line. Theor. Appl. Genet. 100: 949 - 955.

Sakai, T., Liu, H.J., Iwabuchi, M., Kohno-Murase, J. and Imamura, J. 1996. Introduction of a gene from fertility restored radish (Raphanus sativus) into Brassica napus by fusion of $\mathrm{X}$-irradiated protoplasts from a radish restorer line and iodacetoamide-treated protoplasts from a cytoplasmic male-sterile cybrid of B. napus. Theor. Appl. Genet. 93: $373-379$.

Schuler, T. J., Hutcheson, D. S. and Downey, R. K. 1992. Heterosis in intervarietal hybrids of summer turnip rape in Western Canada. Can. J. Plant Sci. 72: 127 - 136. 